\title{
Religion in the US during the time of a Pandemic: A Medical Perspective
}

\author{
Dacre Knight $^{1}$ D $\cdot$ Daniel V. Dudenkov ${ }^{1} \cdot$ William P. Cheshire ${ }^{2}$
}

Accepted: 21 July 2021 / Published online: 2 August 2021

(c) The Author(s), under exclusive licence to Springer Science+Business Media, LLC, part of Springer Nature 2021

\begin{abstract}
Approximately $80 \%$ of Americans identify as religious. As physicians caring for patients with COVID-19, we have seen both positive and negative effects of religious activity during the pandemic. Religious worship generally supports close social interaction, which provides many benefits, especially in mental health, but it can also contradict infection control measures. These forces do not necessarily have to be in opposition to each other. Herein, we present three case vignettes of religious patients who were infected with and recovered from COVID-19. We review the potential benefits and risks of religious activity in the current pandemic, as supported by the medical literature. Finally, we offer some thoughts on how to engage with patients so that the benefits of both religious activity and public health measures are optimized.
\end{abstract}

Keywords COVID-19 $\cdot$ Religion $\cdot$ Coronavirus $\cdot$ Public health $\cdot$ Faith

\section{Introduction}

Since the first cases of COVID-19 were observed in China around December 2019, the causative virus, SARS-CoV-2, quickly spread across the globe (Holshue et al., 2020). The historical record of past pandemics informed clinicians and policymakers, but no one alive had firsthand experience of a public health disaster of this magnitude. Researchers have been working with feverish energy to fill that void of knowledge. And it has paid off. Presenting symptoms are more recognizable. Predicting the course of illness and expected outcomes has advanced ( $\mathrm{Li}$ et al., 2020). Patterns of transmission can be predicted, allowing preventative measures to be

Dacre Knight

knight.dacre@mayo.edu

1 Division of General Internal Medicine, Mayo Clinic, 4500 San Pablo Rd., Jacksonville, FL 32224, USA

2 Department of Neurology, Mayo Clinic, Jacksonville, FL 32224, USA 
established that can reduce the rate of infection. The rise in cases following relaxation of public health measures is also illustrative of the expected outcomes of transmission. But despite the considerable knowledge gained, there is an equal, if not larger amount yet to be discovered. A debate has persisted on the nuances of infection control by preventative measures, particularly social distancing (e.g., "Coronavirus Disease 2019" 2020). Though well intentioned, the impact of distancing has been nearly catastrophic to those reliant on social engagement.

The impact of religion during a pandemic is important as social engagement is a cornerstone in most religious communities. There are proven medical benefits to religious involvement (Mueller et al., 2001). Religious individuals may have a longer life expectancy (Koenig et al., 2012) and decreased medical complications, particularly as they relate to mental health (Koenig \& Cohen, 2002). Conversely, there is also potential for harm. Outbreaks associated with large gatherings can threaten public health during a pandemic. These outbreaks may devastate entire communities. Thus, the decision to attend religious services versus comply with social distancing is not always easy. For some individuals, the perceived incalculable value derived from religious social involvement is weighed against the uncertain or confusing probability of spreading the virus or dying from COVID-19. Therefore, it is crucial that the medical community provides direction to balance and preserve the positive attributes of spirituality and social distancing without unduly infringing on the basic rights to good health and freedom of religion.

In this report, we provide three case vignettes, typical of COVID-19 on most accounts, with a focus on the religious ramifications of the effect of the pandemic from a physician's perspective. We then review the medical history and literature surrounding the interplay of religion and health. Finally, we propose strategies for finding an acceptable balance between the benefits of religious activity and the potential harms to public health.

There is a need to review definitions, as these can vary widely. For ease of understanding the present topic, broadly accepted meanings will be used. Religion defined here as a particular system of faith and worship, and spirituality, the essence of being human (having a soul and inner-life), assumes many forms of practice (OUP 2020). Depending on the definition, some estimate that there are thousands of different religions. The most prevalent include Christianity and Islam, with over 3.5 billion adherents worldwide (e.g., "Global Religious Landscape" 2012). The cases described here were all members of the same Christian church. These patients were seen at an academic medical center that established an entirely virtual COVID-19 clinic to reduce emergency department traffic, while maintaining close monitoring of infected patients (Jethwa et al., 2020). The authors recognize that these cases are not representative of all religions, faiths, or other cases in which religiosity and the COVID-19 pandemic overlap, but they do provide insight on common scenarios in the clinical setting (Miller et al., 2020). 


\section{Case Vignettes: Background}

The three cases presented are members of the same church, a large Pentecostal Christian church in Northeast Florida. The lockdown in Florida was instituted on April 3, 2020. In May 2020, a phased reopening was initiated. By June, indoor gatherings of up to 50 people were allowed if appropriate social distancing recommendations were upheld. A local city mask mandate in public areas was instituted in June 2020 and was in effect until March 2021.

The church discontinued live services when the lockdown began in April 2020 and reopened in June 2020. During the closure, the church invested heavily in live broadcast equipment and began to conduct online broadcasts every weekday night. Each broadcast featured a different family sharing their stories and leading a prayer for the congregation. This became a popular event. More than 32,000 people subscribed from over 20 countries, including the US, Cuba, Saudi Arabia, and Russia. Another innovative program by the church during the lockdown was roadside visitations of those ill with COVID-19. Food and essential household items were left at the door. As government officials relaxed regulations, the church began gathering in small home groups for fellowship and prayer. In June 2020, the church opened its doors to live worship services without any limits on number of attendees. The facilities were sanitized frequently, and masks were made available to everyone. Physical contact was discouraged, and individuals who had any symptoms or who were in contact with someone at home with symptoms were encouraged to stay home and watch the services live online.

\section{Case 1 A Religious Leader}

The patient is a 50-year-old man, the assistant pastor of the aforementioned church, with no significant past medical history. At the end of March 2020, he developed worsening symptoms of cough, fever, and shortness of breath. The patient had no recent travel or known exposure to confirmed cases of COVID-19. Nevertheless, he decided to self-isolate at the first sign of his symptoms. His test for SARS-CoV-2 was positive. His symptoms were mild, so he was advised to remain at home and self-isolate. He followed self-care measures as guided by his physicians. Two days later, he was admitted to the hospital for acute hypoxic respiratory failure secondary to COVID-19. He was treated with antibiotics, supplemental oxygen, inhaled albuterol, corticosteroids, and hydroxychloroquine. During the hospitalization, he was not allowed any visitors, but he maintained virtual contact with family and many church members. After four days, he improved and was discharged home. He had no further exacerbations and remained quarantined for 14 more days. He then resumed working with his congregation.

Upon follow-up with the patient in late October 2020, he shared several thoughts and insights of interest. First, although he acknowledged that the pandemic was a serious matter, he saw the whole situation as being mostly political rather than medical. He thought the government crossed a line by imposing regulations, especially toward churches. He was appalled that "they would recommend people not pray or 
sing together, while Home Depot and resorts in Orlando were packed." Second, he stressed that humans yearn to be in fellowship with others. He frequently encountered congregants who were being negatively affected by loneliness and isolation. He equated the lockdown to putting innocent people in prison-people whose health may already be fragile. Despite having lived through the infection himself and witnessing several friends throughout the world die from the disease, he felt that close fellowship was still crucial for the overall health of his congregants. He compared online services to "watching someone cooking on television," and in-person fellowship as "eating real food." Third, he did acknowledge that the church must be wise to not impart any unnecessary risk to its community. However, he conceded that, despite the above precautions recommended by the church, a large percentage of the members (including church leaders) did not follow the recommendations. He made the point that for 70 years the Soviet Union had restricted the freedoms of Slavic people, so they want to be free. Thus, even though the church frequently sanitized high traffic areas, most of the attendants did not practice social distancing. They often exchanged handshakes and hugs and did not wear masks. Throughout October 2020, multiple congregants became ill, many with COVID-19. In-person church attendance decreased dramatically, and precautions were then taken more seriously. Finally, the patient wanted to send a message to the medical community to say, "stay away from politics." It was his impression that medicine, by having become too political, has lost its credibility. When asked to clarify, the patient brought up issues related to the pandemic that had become partisan and added to the confusion of his disease.

\section{Case 2 A Congregant}

The patient is a 61-year-old man who attends the above church. He presented to the emergency department complaining of fever, cough, and dyspnea. He was discharged on oral azithromycin and later notified of his positive test result for SARS$\mathrm{CoV}-2$. He suspected that he contracted the infection from his pastor at his church as he was not aware of any other known exposures. He had shaken hands with his pastor approximately one week before the onset of his symptoms. The pastor was not known to have COVID-19 at the time. The patient's symptoms fluctuated for almost 2 months before finally improving. He remained in isolation until he had two consecutive negative tests for SARS-CoV-2.

The patient shared his thoughts during his infection as well as in a follow-up interview in October 2020. He stated that he decided to return to his church almost immediately after completing his prescribed period of isolation, and after the church had reopened. Although he acknowledged that the pandemic was serious, he was convinced there was a group of people behind the whole situation, with purposeful infection of the population to achieve various goals. Interestingly, even though he knew many fellow Christians who were infected and had even died, he held a conviction that, "the infection has no right to enter the bodies of true believers because Christians are special people through faith." Nevertheless, he senses that many people are not taking the pandemic seriously. He proclaimed, "we need to be wise and 
balanced." He did not believe that masks help, but he did think that people should avoid physical contact and stay home if they or someone in their household is ill. When further asked about his own treatment experience, he expressed significant frustration with the lack of treatment options even when he was feeling horrible at home. He felt like he received no help from the doctors, only medical bills. He was convinced that there are plenty of treatments available, and that the medical community was simply washing their hands clean of any responsibility by claiming there was no scientific evidence in support of any specific treatment.

\section{Case 3 A Family Member}

The patient is a 63-year-old woman, the wife of the patient in Case 2. She contracted COVID-19 from her husband. Her symptoms progressed through her illness to include fatigue, sore throat, fever, and cough. She had several comorbidities, including hypothyroidism, hypertension, and type 2 diabetes mellitus. On arrival to the emergency department, her chest radiography was clear. She was given a prescription for oral azithromycin. Her test for SARS-CoV-2 returned positive. She was monitored at regular intervals and showed signs of improvement after two weeks. Forty-four days after her initial positive test, she tested negative. At that time, due to her frustration of repeated testing, she requested to be discharged from isolation by endorsing improvement of her symptoms. She was happy to be reunited with her grandchildren and extended family. Her views on the pandemic evolved over the period of her illness. She took it very seriously at the onset. The initial news about the pandemic scared her. When her symptoms increased in severity, she became more worried. But as she recovered and continued her isolation, she ached to reconnect with loved ones. She did not blame her husband for getting her sick. She added that her faith was very important to her. She believed it was God's will. She also believed that she would be protected, and this would be ensured if she maintained her religious activities. When asked at what point did that benefit of protection outweigh the risk of infecting herself or others, she stated she did not want to harm others, so she was willing to follow the recommendations of the doctors. As soon as she was released from isolation, she was happy to reconnect. She tried to follow the guidelines on infection prevention as best as she could, but she admitted it was difficult.

\section{Potential Harms of Religion in a Pandemic}

As illustrated in Case 1, whenever there is difficulty understanding or trusting scientific recommendations, there is a potential for harm. Controlling the behaviors or questioning the dogma of hundreds of millions of religious believers is an insurmountable challenge, but there is still much that medical professionals can do to serve as good stewards and neighbors to protect the health of their patients. What made the patient views in the above vignettes (common among many faiths) potentially problematic is the obligatory practice of faith expression. Religion 
comes in many forms, and without generalizing all behaviors, it is fair to say that some are more participatory than others. Many involve singing, dancing, and shared consumption. Overarching all of these actions, there is a strong tendency for religious people to gather closely for fellowship. However, congregating in any number adds to the risk of infection (Levin, 2009). As over $80 \%$ of the US population believe in God or a "higher power" (Collier et al., 2020), it is easy to see how pervasive religious beliefs can affect the health of many.

Public health aims to mitigate the spread of infection through four main tenets: hand hygiene, social distancing, face coverings, and testing (e.g., "Technical guidance" 2020). Social distancing may be the most difficult for devout religious individuals to follow. The original public health dictum in the 1930s and 1980s, to keep at least three feet apart through outbreaks, doubled after the first SARS outbreak in 2002 when cases of transmission were recorded at distances even greater than six feet. To be more acceptable to society and more effective than three feet, the compromise of a 6-foot rule was set (Gawande, 2020). But the maxim is generally the more distancing the better.

Religious gatherings have been notable "super-spreaders" of infection worldwide when social distancing was not practiced. In Korea, a 61-year-old woman was the first congregant at Shincheonji Church of Jesus in Daegu to test positive (Shin et al., 2020). While it was unclear where she contracted the virus, within two days 15 people connected to the church also tested positive. Just over a month later, the Shincheonji church cluster accounted for 5,080 confirmed cases of COVID-19-more than half of South Korea's total at the time. Prayer gatherings organized by the Tablighi Jamaat, a global Islamic evangelical movement of Indian origin, included more than 3000 people between March 10 and March 15, 2020, from Indonesia, Jordan, Yemen, Saudi Arab, China, Ukraine, Malaysia, Sri Lanka, Afghanistan, Bangladesh, and India. At least ten died and over 100 were infected, with much higher numbers estimated (e.g., "Coronavirus in India" 2020). In France, a five-day prayer meeting at the evangelical church, Christian Open Door, had over 2500 in attendance. At the time, France had only 12 confirmed cases of COVID-19. Less than two months later, there were 57,000 cases. While this church was not the only source of spread, it did appear to be the initial spark for previously untouched areas like Strasbourg, Orléans, Nîmes, Dijon, Corsica, and Burkina Faso after attendees returned home to those areas carrying infection (McAuley, 2020). A funeral ceremony in Albany, Georgia, led to more funerals when at least one of 200 mourners spread the infection (Barry, 2020). Wiping of tears, hugging, crying, and consoling drove a cruel twist of fate. Eventually, the local Albany hospital reached capacity after what was described as an infectious atomic bomb. The National Guard was brought in, and additional (more restricted) funerals were arranged. It is impossible to collect all the numbers of those tied to each event, but it might be in the hundreds of thousands.

These religious niduses of infection continue as long as there are those who do not heed the public health warnings. But embracing the requirement for social distancing is not easy. Humans are social creatures who thrive on the support and beneficence of others. Distancing can be especially difficult for the religious-minded who prefer to counteract the ill effects of isolation by worshiping and communing 
with others. Jewish leaders in New York openly opposed government authorities on this topic of preserving religious gatherings, to the point of bringing lawsuits alleging anti-Semitic discrimination (Neumeister, 2020), and yet this socioculturally bound community has been determined to be a source of outbreaks (Zyskind et al., 2021).

Social distancing errors are not the only source of potential religious harm in a pandemic. There is also a risk of religious scapegoating. For example, after being blamed for causing the pandemic, some Muslims in India suffered from hindered medical care for COVID-19 (Sarkar, 2020). The power of false belief is dangerous when one religious group can be blamed by another religious group for something science has proven untrue. Additionally, emphasis on spiritual devotion has led some to believe that the efficacy of prayer or belonging to their particular faith community provides miraculous protection, making masks or social distancing unnecessary dictates of science (Baker et al., 2020). Whether through discrimination, demographic disadvantages, careless interpretation of Scripture, or simply dogmatic stubbornness, problems ensue whenever strongly held beliefs refute science.

\section{Potential Benefits of Religion in a Pandemic}

Likewise, whenever scientific reductionism overlooks the benefits of religious belief, other problems ensue. Through all the potential harms, there are aspects of religious activity that can lessen the negative effects of a pandemic. Scientifically proven health benefits of religious involvement can serve all humans in various ways. The practice of communal care for the ill and infirm is common among many religions (Cheshire, 2003), including during pandemics (Hoehner et al., 2020). The level of engagement in faith may also be associated with the degree of benefit. In some studies, increased religious attendance correlates with decreased mortality (Mueller et al., 2001). Possible immunologic effects of attendance showed varied levels of the cytokine, interleukin-6, which has a central role in immune defense against infections (Lutgendorf et al., 2004). Religious coping also has shown benefit in mitigating the harmful effects of tragedy and stressful events (Ironson et al., 2017).

In their article in JAMA Internal Medicine, Li et al. showed that religious attendance was associated with a $33 \%$ decrease in all-cause mortality in a sample of 74,000 women ( $\mathrm{Li}$ et al., 2016). This was connected to decreased rates of depression and smoking and increased levels of social support and optimism. Other similar studies have shown that religious attendance equates with increased physical activity, number of meaningful relationships, marriage, and decrease in smoking (Strawbridge et al., 2001). Another study that showed increased attendance correlating with lower mortality posited that there is a "village effect" whereby the community acts as a social support mechanism, just like a small village. Participation in this village dynamic leads to an improved sense of well-being (Musick et al., 2004). Research on the Black Women's Health Study showed that religiosity and attendance decreased all-cause mortality (VanderWeele et al., 2017).

Religion also affects other aspects of health. An HIV diagnosis increases religiousness and spirituality and consequently predicts slower disease progression 
(Ironson et al., 2006). Religious attendance also positively correlates with lower viral loads of HIV 12 months after diagnosis (Van Wagoner et al., 2016). There is a significant inverse relationship between spiritual/religious practices and depressive symptoms (Dalmida et al., 2009). Religion-centered traits, such as increased levels of hope, are associated with a reduced probability of all-cause mortality (Long et al., 2020). Religion in adolescence helps promote improved health later in life, as noted in another study out of Harvard (Chen \& VanderWeele, 2018). Religious attendance increases psychological well-being, healthy behaviors, and character strength, while decreasing mental illness (beyond prayer and meditation alone, though those also help) (Schlitz, 2005).

Further unstudied potential benefits of religion are numerous, but even with these described here, it is plain to see that there can be great benefit to religion at a critical time, such as during a pandemic. A healthy immune system is critical to every severe case of COVID-19. A boost in resilience has not been needed more widely since World War II. And with the chilling number of COVID-19 deaths, any fraction of improvement in mortality can potentially save thousands of lives.

\section{Discussion}

As providers for the patients described in the above cases, sharing an understanding and willingness to accept the patients' religious beliefs entrusted them to our guidance. It strengthened their adherence to the medical recommendations at that time pertaining to isolation and re-testing. Discussing religion and spirituality with these patients gave them hope that doctors were present and willing to help, not in opposition to their faith, but accepting of the value it held for them in their lives. The importance of this joined effort of medicine and religion during a pandemic cannot be emphasized enough. Religious practice, rituals, and ideals have been proposed as important topics for research in relation to the COVID-19 pandemic going forward because they are so intertwined (Baker et al., 2020).

It is a myth that religion should be considered a taboo subject when taking the medical history of a patient. Sexual health was at one time under this classification, but no longer (Collier et al., 2020). Personal religious beliefs are vital knowledge, as the patient in Case 1 described human beings as "created for fellowship" with God and with one another. Understanding the patient's religious beliefs during a pandemic informs the clinician about possible views in opposition to medical science and helps the clinician to navigate respectfully and compassionately the discussion on requirements of isolation and quarantine. Neglecting discussion of religion during the medical encounter is a grave omission that can lead to an impasse in communicating medical recommendations and worsen the mental health consequences of isolation.

Through the duration of illness in the above cases, the provider-patient relationship was important to maintain. While $51 \%$ of Americans believe religion to be "very important," physician views are mixed, with some studies showing physicians endorsing the importance of engaging with patients' spiritual concerns (Smyre et al., 2017) and others reporting that physicians do not consider the religion of their 
patients as a critical determinant of health (Brenan, 2020). Regardless of physician perception, spiritual needs are present during any illness, surveys suggest these needs are not always met (Mueller et al., 2001). Healthcare is strained by access to care, leaving clinicians with limited time to discuss spiritual needs; however, simple screening tools can quickly facilitate acquisition of important social, spiritual, and religious information (Borneman et al., 2010). Human beings are social creatures who thrive with the support of others. This support has been severely damaged by measures to limit spread of the pandemic (Galea et al., 2020). It behooves physicians, in collaboration with their patients, to explore ways for their patients to maintain social connection while distancing. Helping patients by inquiring about their faith background in a nonjudgmental way and affirming their participation in their own religion is supportive in a way that does not impose the clinician's personal religious beliefs on the patient. Such affirmation can be accomplished by drawing attention to medically useful aspects of religious activity, without connecting to any named religion, unless requested by the patient.

Clinicians should be aware that patients' religious views are diverse. They are not always fixed or representative of their religious community but may be individually derived, drawing from personal experience, individual interpretation of excerpts from Scripture, beliefs taught within the family or in school, and partisan news broadcasts or social media. Furthermore, not all churches offer in-depth or systematic teaching on the meaning of illness, the theology of healing, or the theistic foundations that led to the birth of the scientific enterprise. For these reasons, when navigating the complex relationship between science and faith, collaboration among clinicians and clergy is recommended. In some cases, religious patients may interpret their illness as a sign of having come under God's judgment or that their faith is not strong enough. Feelings of guilt, if not addressed, may undermine the beneficial effects of belonging to a faith community. Addressing such feelings of guilt is usually beyond the professional role of the physician, who may lack theological training, and referral to the patient's clergy or elder within the patient's faith community is recommended. There is much that clinicians can do to support religious patients (see the "ARCTIC" strategy in Table 1).

The need for physical separation does not mean that there must be social separation (Morris, 2020). For example, it is better to use phrasing such as "physical distancing" rather than social distancing, to avoid confusing limits on social engagement. Many desperately need social interaction, and there are ways it can be safely carried out. Connections with friends and family should be encouraged, whether web-based or by telephone. Even for the physician to simply inquire about the state of isolation is an important place to start. For the younger and more able-bodied, physicians may suggest reaching out to elder or feebler friends and family to check on their mental health and encourage them to seek further care if needed.

There are demographic obstacles with telecommunication. University of British Columbia professor of religion, Sabina Magliocco, pointed out that the trend in practicing socially distanced religion online favors only the privileged who have access to technology (Magliocco quoted in "Religion in the Age of COVID-19" 2020). A recent study published in JAMA Internal Medicine showed that over $30 \%$ of US adults are not telemedicine-ready (Lam et al., 2020), so it can be assumed that 
Table 1 What clinicians can do to support religious patients (acronym ARCTIC)

\begin{tabular}{ll}
\hline Ask & In a compassionate and nonjudgmental manner, inquire about the patient's spiritual back- \\
ground and practices & \\
Recognize & Take a spiritual history. This allows the clinician to recognize potential benefits available to \\
& patients within their faith community, such as social support and resources for emotional \\
& resilience; and potential risks, such as aversion to science, distrust of medical advice, or \\
& nonadherence to infection control measures \\
Care & Show interest in the religious beliefs of a person of faith as this demonstrates respect for the \\
& patient's beliefs and care for the patient as a whole person \\
Trust & Establish and build upon trust in the care relationship by affirming that the patient's religious \\
& beliefs have meaning for the patient and will be respected. This does not require the clini- \\
cian to agree with those beliefs & \\
Inform & Communicate that religion and science are not antithetical, that both rely on an element of \\
faith when all the facts are not known. Discuss the proven medical benefits of religious \\
involvement. Present scientifically informed medical science accurately and when possible, \\
correct misinformation derived from partisan or alarmist sources \\
Educate and assist patients in seeking ways, through innovative technology or other appro- \\
priate means, to avoid social isolation and remain socially connected when direct physical \\
contact is not advised. Educate patients about appropriate screening, immunization, and \\
treatment. Collaborate with clergy regarding spiritual matters within appropriate bounda- \\
ries of confidentiality
\end{tabular}

they are also unlikely able to access religious services online. Those with limited resources may still choose to congregate in-person, or else be left out. Clinicians and religious leaders can work together to apprise methods that maintain social connection for the underprivileged.

Even though the joint effort is crucial, there has been concern that the pandemic has exacerbated the rift between religion and science ("Living on a Prayer," 2020, 46). Author and atheist, Christopher Hitchens, was prolific in his examples of harm in religion (Mann et al. 2007). This is a time when that harm is unmistakable. In addition to causing super-spreader events, Levin has pointed out examples of other religious blunders, such as priests summoning the "Wind of God," and other phony treatments that may lead to poorer outcomes by providing a false sense of security (Levin, 2020). Choirs singing in close quarters have been characterized as petri dishes for viral growth ("Churches Could be the Deadliest Places in the COVID-19 Pandemic" 2020). Additionally, the hazard of large gatherings regularly comes to debate, as religious patients maintain that church is as essential as grocery stores and restaurants (similar sources of infection), being food for body and soul. However, while loving your neighbor is in fact an act of loving God (VanderWeele, 2020), it is easier said than done when loving your neighbor demands isolation.

Among all the harm, we reviewed potential benefits. Indeed, those who are religious-minded may be better prepared to deal with stress and confusion when science does not have all the answers. For example, at the time the above cases were managed, a test-based strategy was used to determine when patients could discontinue isolation. Set forth by the CDC, isolation was advised until two negative tests had been attained ("Coronavirus Disease 2019" 2020). However, some studies have shown that no live virus could be grown from viral particles after 8 days (Wölfel, 
2020), yet a patient could test "positive" for many weeks (Woodruff et al., 2020). It did not seem to make sense why testing would be necessary to continue for weeks if the virus could not be cultured after more than one week. Patients were frustrated by the seemingly contradictory science behind these recommendations. Further examples of confusing information were when initially experts advised against masks (Chan et al., 2020) and advocated for Plaquenil and against corticosteroids (Yong, 2020). The New England Journal of Medicine and The Lancet famously retracted articles on COVID-19 research. They had to come to terms with how easy it was to lose trust and how difficult it was to regain it (Marcus, 2020). All of this confusion added to the frustration of our patients and highlighted the risk of asking too much from a patient who may be near their limit of confidence and trust. Problems with mistrust partly explain why there are many people ready to gather closely too soon. What is clear is that, during the pandemic, patients are asked to follow recommendations in the absence of solid evidence, with the goal of increasing the margin of safety.

All of this suggests an opportunity for clinicians to explain the uncertainties of science to those who practice their faith regularly. Both science and faith involve trust. For both science and faith, the facts are not entirely established, and one decides to trust in what makes the most sense. Being familiar through their faith with the need to trust in what is unseen when facts are incompletely known, religious people might be better prepared to trust in medical science if it is presented to them as having an evolving factual basis. Some, but not all facts are known, and trusting in medical science, as in religion, need not be a blind faith, but rather one that is grounded in reason and supported by a definite yet incomplete knowledge of reality.

The importance of building such trust cannot be overemphasized. When faith in science is lost, there will be greater challenges for a healing partnership. Sustaining the credibility of medical science demands a limitation of bias, including religious and political biases; and in its application, this requires a balance between respect for patients' religious faith and the practical necessity of employing political means to convey public health recommendations.

Belief without proof has had a long-storied place in healthcare. As William Osler, the father of modern medicine, styled in the British Medical Journal article The Faith that Heals, "faith has always played a strong role as a popular measure of cure" (Osler, 1910). Those of faith should take this as an opportunity to lead by example to achieve the best outcome for themselves and others. Even Richard Dawkins, the Oxford atheist evolutionary biologist, uses the phrase "magic of reality" (Dawkins, 2012). Reality or not, appealing to mystery has value when relating to others. Genig argues that treating the patient at a post-modern level, understanding the individual person and not getting lost in the weeds of chemistry, will aid the curative intent of health professionals (Genig, 2020). Science aids understanding, but avoiding reductionism and the perception of humans as a mere collection of atoms will bring greater success. There is a strong connection between what the WHO describes as health involving physical, mental, and social well-being and what many religions maintain as a trinity of body, mind, and spirit (World Health 
Organization 2020). This is the same "fabric" of life for all human beings and is the seat of feeling, which is beyond proof.

While there is still no validated cure for COVID-19, there are now several safe and effective vaccines and many supportive treatments for the physical effects of the disease. Treatment options for the psychological effects of disease include psychotherapy, social support, prayer, meditation, and fellowship. Each one should be used to its fullest capacity during a pandemic, but these can be a challenge for those who do not have access to care. Magliocco observed that religion is needed even more now during the pandemic, but it is harder to practice (Magliocco quoted in "Religion in the Age of COVID-19" 2020). Further research needs to be done to develop strategies that can be applied to support this health-serving matrimony of public health and religion in the time of a pandemic.

Admittedly, this is not without difficult questions. It is clear to see what religious activity helps, but until there is more research on how and why there is a benefit, this will remain a contentious topic. Some have proposed the pandemic has accelerated secularization (Baker et al., 2020) or the transition from a religious to a secular political ideology (Hamid, 2021). Nevertheless, it is still possible to prevail in applying the known benefits of religious activities and preserving life as this research carries on. These case vignettes serve that purpose in highlighting the medical attributes of this disease and the possible treatments derived from the good of religion. Personal philosophical, religious, and spiritual belief systems can influence both exposure to disease and willingness to receive treatment, and when practiced with careful attention to safety, can lead to improved health outcomes. These case vignettes also provide examples of religious patients who were not fixed in their views but modified them as they experienced illness and learned from clinicians they trusted.

This study is not without limitations. For one, we present three patient vignettes from a single church of a specific denomination within Christianity. Their experience cannot be easily generalized to other religions. In our review of the literature, it is clear further research is needed to inform the medical community as to how to engage with patients whose religious activities pose a threat to the public good. In this paper, we propose strategies that may be fruitful toward serving the providerpatient relationship. But outside of the provider-patient encounter, more guidance is needed to effectively educate whole patient populations. This will help enact public health policies that may strike a balance between promoting religious freedom, while limiting harm to the public during a pandemic. Those who cherish freedom of religion should also respect the right to safety. A classic public health ethics dilemma is manifested by this pandemic: individual privacy rights versus public health, e.g., the Tarsoff decision "the right to privacy ends where public peril begins (Buckner and Firestone 2000)." The pandemic is both a proving ground and a desperate situation. It will require further research and careful thought on both individual and population health levels.

There is a famous story in the Gospels where Jesus Christ, prior to beginning his ministry, retreated to the wilderness for 40 days, the same amount of time that in antiquity merchant Mediterranean ships were ordered to be kept in isolation when arriving at port to limit the spread of bubonic plague ("History of Quarantine" 2012). Whether the derivation of the word "quarantine," which signifies 40, is 
a biblical reference with infectious disease implications, we may never know, but we do know that the ancient Greeks, prior to Christianity, were in agreement, as Hippocrates distinguished plague as a disease that manifested within 40 days of contact (Conti, 2008). Religion and health have shared a long interplay through history and will continue to do so. We can learn how to counter the ill effects of risky religious activities and reduce infectious outbreaks within, rather than in opposition to, communities of faith if we continue to work together, learn from the past, and take care with how we proceed.

\section{Conclusion}

Mental health, economics, and public health collide within the topic of religion during the chaos of a pandemic. Public health favors isolation. Isolation harms economic activity and mental health. Religious activity generally supports social interaction, which is in contradiction to infection control initiatives. But these forces do not necessarily have to be in opposition to each other. There is an ideal balance to be found between social connection and spread of disease. This balance undergoes continual readjustment as more information becomes known and disseminated. The promotion of cohesion between medical science and religion requires medical literacy, education, collaboration, and understanding religious and spiritual dimensions in the health history of every patient while supporting public health measures.

Author Contributions All authors contributed to the study conception and design. All authors read and approved the final manuscript.

Funding The authors did not receive support from any organization for the submitted work.

Availability of data and material Available upon request.

Code availability Not applicable.

Declarations

Conflicts of interest The authors have no relevant financial or non-financial interests to disclose.

Informed consent Informed consent for the publication of patient clinical details was obtained from all participants for whom identifying information is included in this article.

\section{References}

Baker, J. O., Martí, G., Braunstein, R., Whitehead, A. L., \& Yukich, G. (2020). Religion in the age of social distancing: How COVID-19 presents new directions for research. Sociology of Religion, 81(4), 357-370. https://doi.org/10.1093/socrel/sraa039 
Barry, E. (2020). Days After a Funeral in a Georgia Town, Coronavirus 'Hit Like a Bomb.' The New York Times. Retrieved July 2, 2020, from https:/www.nytimes.com/2020/03/30/us/coronavirusfuneral-albany-georgia.html.

Borneman, T., Ferrell, B., \& Puchalski, C. M. (2010). Evaluation of the FICA tool for spiritual assessment. Journal of Pain and Symptom Management, 40(2), 163-173. https://doi.org/10.1016/j.jpain symman.2009.12.019

Brenan, B. M. (2020). Religion considered important to $72 \%$ of Americans. Gallup.Com. https://news. gallup.com/poll/245651/religion-considered-important-americans.aspx.

Chan, A., Leung, C., Lam, T., \& Cheng, K. (2020). To wear or not to wear: WHO's confusing guidance on masks in the covid-19 pandemic. The BMJ. Retrieved May 24, 2020, from, https://blogs.bmj. com/bmj/2020/03/11/whos-confusing-guidance-masks-covid-19-epidemic/.

Chen, Y., \& VanderWeele, T. J. (2018). Associations of religious upbringing with subsequent health and well-being from adolescence to young adulthood: An outcome-wide analysis. American Journal of Epidemiology, 187(11), 2355-2364.

Cheshire, W. P. (2003). Twigs of terebinth: The ethical origins of the hospital in the Judeo-Christian tradition. Ethics \& Medicine, 19(3), 143-153.

Churches Could be the Deadliest Places in the COVID-19 Pandemic. (2020). Infection Control Today. Retrieved May 23, 2020, from https://www.infectioncontroltoday.com/view/churches-could-bedeadliest-places-covid-19-pandemic.

Collier, K. M., James, C. A., Saint, S., \& Howell, J. D. (2020). Is it time to more fully address teaching religion and spirituality in medicine? Annals of Internal Medicine, 172(12), 817-818. https://doi. org/10.7326/m20-0446

Conti, A. A. (2008). Quarantine through history. International Encyclopedia of Public Health. https://doi. org/10.1016/2FB978-012373960-5.00380-4

Coronavirus Disease 2019 (COVID-19). (2020). Centers for Disease Control and Prevention. Retrieved 4 May, 2020, from https://www.cdc.gov/coronavirus/2019-ncov/prevent-getting-sick/social-dista ncing.html

Coronavirus Disease 2019 (COVID-19). (2020). Centers for Disease Control and Prevention. Retrieved May 12, 2020, from https://www.cdc.gov/coronavirus/2019-ncov/hcp/disposition-in-home-patients. html.

Coronavirus in India: Tablighi Jamaat Meet Turns Covid-19 Super Spreader. (2020). India Today. Retrieved June 17, 2020, from https:/www.indiatoday.in/mail-today/story/coronavirus-in-india-tabli ghi-jamaat-meet-turns-covid-19-super-spreader-1661958-2020-04-01.

Dalmida, S. G., Holstad, M. M. D., Diiorio, C., \& Laderman, G. (2009). Spiritual well-being, depressive symptoms, and immune status among women living with HIV/AIDS. Women \& Health, 49(2-3), 119-143. https://doi.org/10.1080/03630240902915036

Dawkins, R. (2012). The magic of reality: How we know what's really true (Reprint ed.). Free Press.

Galea, S., Merchant, R. M., \& Lurie, N. (2020). The mental health consequences of COVID-19 and physical distancing. JAMA Internal Medicine, 180(6), 817. https://doi.org/10.1001/jamainternmed.2020. 1562

Gawande, A. (2020). Amid the Coronavirus Crisis, a Regimen for Reentry. The New Yorker. Retrieved July 14, 2020, from https://www.newyorker.com/science/medical-dispatch/amid-the-coronaviruscrisis-a-regimen-for-reentry.

Genig, J. D. (2020). A more excellent way: Recovering MYSTERY in COVID care. Journal of Religion and Health, 59(5), 2302-2307. https://doi.org/10.1007/s10943-020-01049-w

History of Quarantine I Quarantine I CDC. (2012). Centers for Disease Control and Prevention. Retrieved May 15, 2020, from https://www.cdc.gov/quarantine/historyquarantine.html.

Hamid, S. (2021). How Politics Replaced Religion in America. The Atlantic. Retrieved March 4, 2021, from https://www.theatlantic.com/magazine/archive/2021/04/america-politics-religion/618072/.

Hoehner, P., Beyda, D. H., Cheshire, W. P., Cranston, R. E., Dunlop, J. T., Francis, J. E., Mitchell, C. B., Onarecker, C., Riley, D. J., Roberts, A. H., Sullivan, D. M., Toevs, C. C., Yates, F. D., \& Hook, C. C. (2020). Triage and resource allocation during crisis medical surge conditions (pandemics and mass casualty situations): A position statement of the Christian Medical \& Dental Associations. Christian Journal for Global Health, 7(1), 45-55. https://doi.org/10.1556/6.cjgh.v7il.387

Holshue, M. L., DeBolt, C., Lindquist, S., Lofy, K. H., Wiesman, J., Bruce, H., Spitters, C., Ericson, K., Wilkerson, S., Tural, A., Diaz, G., Cohn, A., Fox, L. A., Patel, A., Gerber, S. I., Kim, L., Tong, S., Lu, X., Lindstrom, S., \& Pillai, S. K. (2020). First Case of 2019 Novel Coronavirus in the United 
States. New England Journal of Medicine, 382(10), 929-936. https://doi.org/10.1056/nejmoa2001 191

Ironson, G., Henry, S. M., \& Gonzalez, B. D. (2017). Impact of stressful death or divorce in people with HIV: A prospective examination and the buffering effects of religious coping and social support. Journal of Health Psychology, 25, 606-616.

Ironson, G., Stuetzle, R., \& Fletcher, M. A. (2006). An increase in religiousness/spirituality occurs after HIV diagnosis and predicts slower disease progression over 4 years in people with HIV. Journal of General Internal Medicine, 21(Suppl 5), S62-68.

Jethwa, T., Ton, A., Paredes Molina, C. S., Speicher, L., Walsh, K., Knight, D., Davlantes, T., \& Francis, D. (2020). Establishing Mayo Clinic's Coronavirus Disease 2019 Virtual Clinic: A Preliminary Communication. Telemedicine and E-Health, 26(11), 1419-1423. https://doi.org/10.1089/tmj.2020. 0145

Koenig, H. G., \& Cohen, H. J. (Eds.). (2002). The link between religion and heath: Psychoneuroimmunology and the faith factor. Oxford University Press.

Koenig, H. G., King, D. E., \& Carson, V. B. (2012). Handbook of religion and health (2nd ed.). Oxford University Press.

Lam, K., Lu, A. D., Shi, Y., \& Covinsky, K. E. (2020). Assessing telemedicine unreadiness among older adults in the United States during the COVID-19 pandemic. JAMA Internal Medicine, 180(10), 1389. https://doi.org/10.1001/jamainternmed.2020.2671

Levin, J. (2009). How faith heals: A theoretical model. EXPLORE, 5(2), 77-96. https://doi.org/10.1016/j. explore.2008.12.003

Levin, J. (2020). The faith community and the SARS-CoV-2 outbreak: Part of the problem or part of the solution? Journal of Religion and Health. https://doi.org/10.1007/s10943-020-01048-X

Li, Q., Guan, X., Wu, P., Wang, X., Zhou, L., Tong, Y., Ren, R., Leung, K. S. M., Lau, E. H. Y., Wong, J. Y., Xing, X., Xiang, N., Wu, Y., Li, C., Chen, Q., Li, D., Liu, T., Zhao, J., Liu, M., \& Feng, Z. (2020). Early transmission dynamics in Wuhan, China, of Novel coronavirus-infected pneumonia. New England Journal of Medicine, 382(13), 1199-1207. https://doi.org/10.1056/nejmoa2001316

Li, S., Stamfer, M., Williams, D. R., \& VanderWeele, T. J. (2016). Association between religious service attendance and mortality among women. JAMA Internal Medicine, 176(6), 777-785.

Living on a Prayer. (2020). The Economist. (April 11), 45-46.

Long, K. N. G., Kim, E. S., Chen, Y., Wilson, M. F., Worthington, E. L., \& VanderWeele, T. J. (2020). The role of hope in subsequent health and well-being for older adults: an outcome-wide longitudinal approach. Global Epidemiology, 2, 100018.

Lutgendorf, S. K., Russell, D., Ullrich, P., Harris, T. B., \& Wallace, R. (2004). Religious participation, interleukin-6, and mortality in older adults. Health Psychology, 23(5), 465-475.

Mann, W., Amis, M., \& Hitchens, C. (2011). The Quotable Hitchens: From Alcohol to Zionism -- The Very Best of Christopher Hitchens (Original ed.). Da Capo Press.

Marcus, A. A. (2020). Lancet, NEJM retract controversial COVID-19 studies based on Surgisphere data. Retraction Watch. Retrieved June 21, 2020, from https://retractionwatch.com/2020/06/04/lancetretracts-controversial-hydroxychloroquine-study/.

McAuley, J. (2020). How a prayer meeting at a French megachurch may have led to scores of coronavirus deaths. Washington Post. Retrieved June 29, 2020, from https://www.washingtonpost.com/ world/europe/how-a-prayer-meeting-at-a-french-megachurch-may-have-led-to-scores-of-coronavirus-deaths/2020/04/01/fe478ca0-7396-11ea-ad9b-254ec99993bc_story.html.

Miller, A. C., Castro Bigalli, A. A., \& Sumanam, P. (2020). The coronavirus disease-2019 pandemic, social distancing, and observance of religious holidays: Perspectives from Catholicism, Islam, Judaism, and Hinduism. International Journal of Critical Illness and Injury Science, 10(2), 49-52. https://doi.org/10.4103/IJCIIS.IJCIIS_60_20

Morris, N. P. (2020). Staying apart during a pandemic. JAMA Internal Medicine, 180(8), 1047. https:// doi.org/10.1001/jamainternmed.2020.2505

Mueller, P. S., Plevak, D. J., \& Rummans, T. A. (2001). Religious involvement, spirituality, and medicine: Implications for clinical practice. Mayo Clinic Proceedings, 76(12), 1225-1235. https://doi. org/10.4065/76.12.1225

Musick, M. A., House, J. S., \& Williams, D. R. (2004). Attendance at religious services and mortality in a national sample. Journal of Health and Social Behavior, 45(2), 198-213.

Neumeister, L. (2020) Jewish leaders call COVID rules "blatantly anti-Semitic." AP NEWS. Retrieved March 10, 2021, from https://apnews.com/article/virus-outbreak-race-and-ethnicity-new-york-discr imination-lawsuits-aaa94a5e496896c545a630c6ebf423c2. 
Osler, W. (1910). The faith that heals. British Medical Journal, 1(2581), 1470-1472. https://doi.org/10. 1136/bmj.1.2581.1470

Oxford University Press (OUP). (2020). religion. Lexico.Com. Retrieved August 24, 2020, from https:// www.lexico.com/definition/religion.

Religion in the Age of COVID-19. (2020). Faculty of Arts. Retrieved August 27, 2020, from https:// www.arts.ubc.ca/news/religion-in-the-age-of-covid-19/.

Sarkar, S. (2020). Religious discrimination is hindering the covid-19 response. BMJ, m2280. https://doi. org/10.1136/bmj.m2280

Schlitz, M. (2005). Meditation, prayer and spiritual healing: The evidence. The Permanente Journal, $9(3), 63-66$.

Shin, Y., Berkowitz, B., \& Kim, M. J. (2020, March 25). How a South Korean church helped fuel the spread of the coronavirus. Washington Post. Retrieved June 7, 2020, from https://www.washington post.com/graphics/2020/world/coronavirus-south-korea-church/.

Smyre, C. L., Tak, H. J., Dang, A. P., Curlin, F. A., \& Yoon, J. D. (2018). Physicians' opinions on engaging patients' religious and spiritual concerns: A National survey. Journal of Pain and Symptom Management, 55(3), 897-905. https://doi.org/10.1016/j.jpainsymman.2017.10.015

Strawbridge, W. J., Shema, S. J., Cohen, R. D., \& Kaplan, G. A. (2001). Religious attendance increases survival by improving and maintaining good health behaviors, mental health, and social relationships. Annals of Behavioral Medicine, 23(1), 68-74.

Technical Guidance. (2020). World Health Organization. Retrieved September 24, 2020, from https:// www.who.int/emergencies/diseases/novel-coronavirus-2019/technical-guidance.

The Global Religious Landscape. (2012). Pew Research Center's Religion \& Public Life Project. Retrieved June 12, 2020, from https://www.pewforum.org/2012/12/18/global-religious-lands cape-exec/.

Van Wagoner, N., Elopre, L., Westfall, A. O., Mugavero, M. J., Turan, J., \& Hook, E. W. (2016). Reported church attendance at the time of entry into HIV care is associated with viral load suppression at 12 months. AIDS and Behavior, 20(8), 1706-1712.

VanderWeele, T. J. (2020). Love of neighbor during a pandemic: Navigating the competing goods of religious gatherings and physical health. Journal of Religion and Health, 59(5), 2196-2202. https://doi. org/10.1007/s10943-020-01031-6

VanderWeele, T. J., Yu, J., Cozier, Y. C., et al. (2017). Religious service attendance, prayer, religious coping, and religious-spiritual identity as predictors of all-cause mortality in the Black Women's Health Study. American Journal of Epidemiology, 2017(185), 515-522.

Wölfel, R., Corman, V. M., Guggemos, W., Seilmaier, M., Zange, S., Müller, M. A., Niemeyer, D., Jones, T. C., Vollmar, P., Rothe, C., Hoelscher, M., Bleicker, T., Brünink, S., Schneider, J., Ehmann, R., Zwirglmaier, K., Drosten, C., \& Wendtner, C. (2020). Virological assessment of hospitalized patients with COVID-2019. Nature, 581(7809), 465-469. https://doi.org/10.1038/ s41586-020-2196-X

Woodruff, A., Walsh, K. L., Knight, D., \& Irizarry-Alvarado, J. M. (2020). COVID-19 infection: Strategies on when to discontinue isolation, a retrospective study. American Journal of Infection Control, 48(9), 1032-1036. https://doi.org/10.1016/j.ajic.2020.06.220

World Health Organization. (1948/2020). Basic Documents (49th ed.). World Health Organization.

Yong, E. (2020). The pandemic doesn't have to be this confusing. The Atlantic. Retrieved May 28, 2020, from https://www.theatlantic.com/health/archive/2020/04/pandemic-confusing-uncertainty/610819/.

Zyskind, I., Rosenberg, A. Z., Zimmerman, J., Naiditch, H., Glatt, A. E., Pinter, A., Theel, E. S., Joyner, M. J., Hill, D. A., Lieberman, M. R., Bigajer, E., Stok, D., Frank, E., \& Silverberg, J. I. (2021). SARS-CoV-2 Seroprevalence and Symptom Onset in Culturally Linked Orthodox Jewish Communities Across Multiple Regions in the United States. JAMA Network Open, 4(3), e212816. https:// doi.org/10.1001/jamanetworkopen.2021.2816

Publisher's Note Springer Nature remains neutral with regard to jurisdictional claims in published maps and institutional affiliations. 